\title{
TEORIA DA MODERNIDADE LÍQUIDA - FLUIDEZ SOCIAL E OS NOVOS DESAFIOS NA INTERPRETAÇÃO DAS LEIS PARA SOLUÇÃO DOS VÁRIOS NOVOS CONFLITOS NO DIREITO DE FAMÍLIA.
}

Eloy Pereira Lemos Junior ${ }^{1}$

Fátima Cristina da Silva ${ }^{2}$

\begin{abstract}
Resumo
A sociedade é muito dinâmica, a evolução acontece de forma descontrolada, tendo isso pontos positivos e negativos. Além de surgirem quantidade grande e naturezas diversas de conflitos, estes às vezes fogem das previsões legais, tendo em vista que nem sempre a legislação acompanha a rápida evolução. Os conflitos são cada vez mais complexos, o que dificulta cada vez mais a aplicação justa do direito. Assim, nesse sentido, surge a necessidade de interpretação mais ampla, da verdadeira hermenêutica que considera o direito como um todo, o direito que está além das leis, e que deve ter como principal fim o de aplicar decisões justas a quem recorre ao judiciário, ou seja, o direito que se baseia nos princípios e direitos fundamentais de cada indivíduo. A metáfora da modernidade líquida, ideia de um sociólogo bastante renomado, "Zygmunt Bauman", tem sido estudada e associada aos novos desafios da aplicação do direito, valendo a pena então seu estudo e entendimento. No presente estudo, a abordagem dará ênfase às grandes e tantas mudanças no que tange ao Direito de família.
\end{abstract}

Palavras-chave: Modernidade. Fluidez social. Conflitos. Interpretação. ZygmuntBauman.

\section{INTRODUÇÃO}

Modernidade Líquida, ideia central do presente trabalho, é uma metáfora desenvolvida pelo sociólogo polonês Zygmunt Bauman, para tratar as tantas e rápidas mudanças nasociedade.

A ideia dos líquidos se contrapõe a tudo o que é sólido e difícil de ser contornado ou modificado. Os líquidos nos remetem também a ideia da fluidez, nesse caso, podemos falar de uma "fluidez social", pois a sociedade nos seus primórdios tinha moldes rígidos, ortodoxos, verdadeiras barreiras que se não fossem contornadas, diluídas, o mundo não poderia evoluir e chegar nem perto do status em que se encontra hoje.

\footnotetext{
${ }^{1}$ Doutor em direito pela UFMG (2007), possui mestrado e especializações. Foi bolsista CAPES (2005) na Universidade de Lisboa, atualmente bolsista FUNDEP-UFMG (desde 2013). Avaliador de cursos de direito pelo INEP-MEC (desde 2010). Atualmente, é professor titular do mestrado e da graduação da Universidade de Itaúna (MG), titular na graduação da UEMG, da FACED - Divinópolis (MG), UNIPAC, UNI-BH e na especialização da UNA-BH. E-mail: eloy.junior@uol.com.br

${ }^{2}$ Bacharel em Direito e Advogada. E-mail: fcs.dir@hotmail.com
} 
Os modelos antigos de sociedade prendiam muito a evolução; as regras, costumes, religião, sempre tentaram impedir a modernidade, e esse então seria o primeiro e grande desafio, o do tempo contra o espaço. Primeiramente, as lutas seriam de contornar ou até mesmo diluir costumes e regras desnecessárias, mudar aqueles moldes antigos para outros moldes diferentes e mais liberais, tendo em vista que independente do estágio de evolução e modernidade sempre há um suposto "molde" para as pessoas se enquadrarem.

A luta pela modernidade não foi fácil, mas também não pôde ser contida, controlada, como os líquidos e gases também não podem ser contidos quando são pressionados a certo destino; não são sólidos, não são estáveis, e é praticamente impossível controlar ou impedir sua mudança.

As primeiras lutas eram do social, da política, na luta pelo espaço e pelo que poderia e podia ser feito naquele determinado espaço. A luta pelo social e política sempre vão existir, mas após tantas mudanças ocorridas, que nos trouxeram para moldes mais liberais, mais modernos, uma mudança que se destacou e ainda se destaca atualmente é a luta da convivência social.

Nesse sentido, aduzimos que todos os moldes antigos e conservadores de relações afetivas e de família foram diluídos, cedendo lugar à liberdade de convivência, à liberdade de manifestação dos sentimentos, independente do tipo de relação. Podemos fazer uma associação ao pluralismo que é defendido pela Nossa Constituição da República no seu preâmbulo, na busca pela igualdade entre os indivíduos, do direito subjetivo que cada um tem perante essa imensa sociedade, restando apenas o desafio da aceitação pela massa dos modelos diferentes de relações de afeto.

Assim, abordando essa fluidez sem controle que nos trouxe à situação atual de pós-modernidade, segunda modernidade ou até mesmo sobre-modernidade, termos usados por alguns estudiosos sociais, nos remetemos à revolução que ocorreu e ocorre na seara do Direito de Família, que na área jurídica, talvez seja uma das áreas que mais tem sofrido mudanças, em leis e principalmente na interpretação (hermenêutica), para se adequar aos casos concretos que são tantos e tão novos. Como já mencionado, a luta que mais se destaca atualmente é a da convivência social, e nessa área, quase todos os moldes foram rompidos, a modernidade em sua liquidez contornou quase todos os padrões e a luta ainda continua, mesmo que seja por uma minoria da sociedade, para mudar ainda mais esse cenário.

Disso tudo que foi exposto, resta-nos alguns questionamentos muito relevantes no presente estudo: Como está a sociedade diante da fluidez social sem controle? Qual tem sido o ritmo das mudanças legislativas para acompanhar os novos conflitos? Quais os sistemas adotados pelo judiciário para solução dos tantos novos casos? Essa modernidade sem limites é totalmente positiva ou traz algum malefício à sociedade e aos indivíduos? Se o ser humano nunca se vê satisfeito com o estado que se encontra, até onde teremos que evoluir para satisfazer as tantas necessidades? 
Todos os questionamentos suscitados serão debatidos neste trabalho; serão buscadas algumas respostas para essas indagações e outras tantas que surgem nesses assuntos que são tão complexos e polêmicos: modernidade, indivíduos e relações sociais ejurídicas.

\section{SÍNTESE SOBRE EVOLUÇÃO DA SOCIEDADE ECONSEQUENTE EVOLU ÇÃO DO DIREITO}

A evolução da sociedade tem ligação direta com a evolução na história, na cultura, e consequentemente na evolução do direito. Há uma interdependência para o melhor estudo e entendimento de ambos os assuntos. Grandes historiadores falam em aparecimento dos primeiros homens há 12 milhões de anos ao Norte da Índia e que o nome desses homens era Romapithecos.

Com o passar dos tempos os agrupamentos foram aumentando, novos grupos foram formados para surgir assim novas civilizações, ou seja, desde os primeiros relatos de existência do ser humano, ele sentia uma necessidade ou talvez um instinto de viver em coletividade, e por isso foram sendo formados os grupos sociais.

A sociedade existe desde que os homens começaram a viver sobre a terra, pois desde os primórdios, para coabitar em um mundo que era desprovido de recursos, já havia luta por alguma forma de poder, imposição de regras por alguém que conseguisse esse almejado poder e os primeiros moldes já começavam a serem impostos para serem seguidos pelos outros habitantes; regras de convivência, regras morais, enfim, as primeiras regras para se viver em sociedade.

\section{As primeiras regras morais e jurídicas}

Como mencionado, desde os primórdios o homem sentiu necessidade de estar em coletividade, de estar em grupos, e nesse sentido, estudos de nossos dados históricos, sociológicos e antropológicos nos mostram que o homem começou a viver em comunidades, sendo que nestas todo indivíduo precisava respeitar os primeiros modelos que eram impostos.

A história nos relata as primeiras regras das sociedades com ligação direta com a religiosidade, ou seja, o direito/justiça no início da nossa historia era exercido pela Igreja. Quem julgava para os homens não era um juiz, uma pessoa física com autoridade de decisão e conhecimentos para tanto, era um Deus que exercia esse poder através dos líderes religiosos/anciãos. As comunidades acolhiam e tentavam resolver os problemas que surgiam, tentavam corrigir e reeducar quem infringia as "regras", fugia dos padrões e em casos mais graves, a decisão era passada para os chefes religiosos que em nome de Deus solucionavam o problema impondo os castigos, "sanções" que a Divindade julgava adequada ao indivíduo que cometeu algum crime, fugiu às regras gerais, aos mandamentos divinos que se confundiam naquela época. 
Nesse sentido, importa ressaltar que quando uma pessoa cometia desvios, supostos "crimes", todos acreditavam que ela estava com um espírito ruim, possuída por forças do mal, por isso eram os líderes religiosos que eram incumbidos da solução dos casos, para que após constatar os problemas expulsassem o demônio que estava nas pessoas que fugiam dos moldes dos agrupamentos. Todos acreditavam que era Deus que aplicava os castigos.

A religião está na gênese do direito e da sociedade, deu base a todo o ordenamento jurídico que temos na atualidade, foi a primeira forma usada para controle social.

\section{Culturalismo jurídico}

Alguns estudiosos usam a expressão culturalismo jurídico, para denominar a evolução através de uma interdependência entre a cultura, a história da sociedade e a evolução do direito.

Nesse sentido, podemos mencionar algumas palavras de Miguel Reale (apud LIMA, Rogério de Araújo; LIMA, Lucas Cavalcante de. 2011.P.1)

[...] A ciência do direito é uma ciência histórico-cultural e compreensivo-normativa, por ter por objeto a experiência social na medida, enquanto normativamente se desenvolve em função de fatos e valores, para a relação ordenada da convivência humana.

O autor acima citado nos leva a concluir que o Direito evolui de maneira a acompanhar a evolução da história, da cultura. Como uma ciência social, o Direito tem como papel estudar e compreender a sociedade de maneira a acompanhar os modelos que está usando como normativos e buscar acompanhar os fatos e os valores. Os fatos mudam de acordo com a época e com a variedade de culturas. A variedade aqui está no tempo e no espaço, e consequentemente nos fatos que decorrem dessas circunstâncias.

Em artigo publicado no site Jusnavigandi.com, Rogério de Araújo Lima e Lucas Cavalcanti de Lima nos esclarecem a importância do Culturalismo Jurídico para estudo da Evolução da Sociedade e Direito:

\footnotetext{
"As formas pelas quais o direito se apresenta são delineadas pelo processo histórico. Para entendê-las é preciso conhecer a cultura dos povos numa relação espaço- temporal. Por isso, a teoria do Culturalismo Jurídico permite-nos vislumbrar o Direito em sua Interrelação necessária com a História". (LIMA, Rogério de Araújo; LIMA, Lucas Cavalcanti, 2011.p.2)
}

Não há uma relação de subordinação, mas de interdisciplinaridade e $\backslash$ ou interdependência entre os estudos. Os autores desse estudo dão destaque ao fator histórico, tendo em vista que cultura será de acordo com a evolução da história e da época; já o direito, naturalmente se formará dentro desse contexto para organizar o funcionamento da sociedade, ou seja, de acordo com as necessidades da época, o direito será uma construção humana para organização da sociedade.

No que tange à cultura, esta se caracteriza pelo conjunto de adaptações que o homem faz na sociedade, sendo certo que depende diretamente do espaço que está se vivendo e também do tempo, pois as culturas 
também sofrem modificações em seus moldes.

Para ilustrar a análise sobre cultura, vejamos palavras de Maria Helena Diniz: "A cultura é o conjunto de adaptações e ajustamentos feitos pelo homem, para que as coisas sirvam aos fins humanos". DINIZ, Maria Helena, 1999.p.132 (apud LIMA, Rogério de Araújo; LIMA, Lucas Cavalcante de, 2011.p.1).

Diante das considerações expostas, pode-se perceber a importância da interligação entre história e cultura para posterior formação do direito que será formado pelo homem de acordo com o ritmo das modificações que ensejarão nas novas necessidades.

Como já destacado, não há uma relação de subordinação entre tais requisitos, mas sim uma interdependência. Não há como se falar em evolução do Direito e Modernidade da sociedade sem analisar todas as mudanças na história, peculiar em cada parte do mundo, com tantas distinções dentro dos próprios países. Assim, podemos dizer que o modelo de Justiça ou "Direito" que temos na atualidade é consequência da evolução histórica que foi modificada pelas diversidades de acordo com as necessidades de cada cultura e ensejaram consequentemente a evolução do direito de acordo com o sentirsocial.

\section{A METÁFORA DA MODERNIDADE LÍQUIDA PROPOSTA POR ZYGMUNT BAUMAN E SUA ASSOCIAÇÃO COM OS NOVOS DESAFIOS DA APLICAÇÃO DO DIREITO}

O autor Zygmunt Bauman ${ }^{3}$ é um sociólogo polonês, estudioso dos fenômenos da transformação da sociedade. Dentre suas obras publicadas, está o estudo da Modernidade sem controle que foi brilhantemente associada à metáfora da "Modernidade Líquida", sendo esta representativa de uma fluidez, que se contrapõe a tudo que é estático e pode ser facilmente controlado. Essa ideia de uma sociedade que muda tão rapidamente como se fosse um líquido que percorre rapidamente por vários caminhos e continua seguindo seu percurso tem uma interessantíssima interpretação quando associada aos desafios do Direito que se formou e se atualiza acompanhando a sociedade, tendo em vista ser uma ciência social tãoimportante.

Sobre as características da fluidez, seguem palavras do criador da Metáfora "Modernidade Líquida": "Fluidez é uma qualidade de líquidos e gases". O que os distingue dos sólidos, como a enciclopédia britânica, com a autoridade que tem nos informa, é que eles não podem suportar uma força tangencial ou deformante quando imóveis, e assim, "sofrem uma constante mudança de forma quando submetidos a tal tensão." (BAUMAN, 2000,

\footnotetext{
${ }^{3}$ Zygmunt Bauman- sociólogo polonês nascido em 1925. Fugiu de seu país de origem no ano de 1939, foi para a Rússia onde permaneceu durante toda a Segunda Guerra Mundial. Após retornar à Polônia se filiou ao Partido Comunista e estudou na Universidade de Varsóvia, onde chegou a ser professor. Algum tempo depois, comandou o departamento de sociologia da faculdade de Leeds. É autor de diversos livros e artigos, a maioria deles escritos após o ano de 1990 quando se aposentou. Todas as suas obras são relacionadas às ciênciassociais.
} 
p.7).

Pensamos, assim, em uma sociedade que se movimenta rapidamente da mesma maneira que um fluxo, que não se fixa em lugar algum, pois a mudança é constante. Assim são os líquidos, assim é o direito, e assim é a sociedade.

Como relatado, desde que o homem se firmou em terra e começou a se juntar em agrupamentos já existiam alguns "moldes" que deveriam ser respeitados, regras legais ou sociais impostos como modelo adequado de conduta. Esses moldes eram muito rígidos, e foi mediante lutas e verdadeiras revoluções que esses moldes começaram a ser transpostos até chegarem ao ponto de serem quase que totalmente diluídos, cedendo lugar ao novo, que sempre cede lugar a algo mais novo ainda, pois o ser humano não se satisfaz com nada quedura.

Certas palavras são comuns na sociedade: interrupção, novidade, transformação. As mudanças chegam, diluem alguns obstáculos, tornam o que já foi atual mais moderno ainda e continuam com seu curso para romper algum outro modelo que com o passar do tempo, pode ser que nem seja muito tempo, se torneobsoleto.

Podemos citar algumas das características dos líquidos, como bem nos descrevem as palavras de Bauman: [...]Eles "fluem", "escorrem", "esvaem-se", "respingam","transbordam", "vazam", "inundam", "borrifam", "pingam", são "filtrados", "destilados", diferentemente dos sólidos, não são facilmente contidos"[...]. (BAUMAN, 2000, p.8)

São inúmeras as características que podemos mencionar para tratar dos nossos tempos líquidos, da nossa "Modernidade Líquida", todos eles nos trazendo o sentido de mutabilidade, de dificuldade de controle, de algo que vem pra romper com obstáculos, de algo difícil de ser contido, pois os modelos são rompidos, invadidos, sendo certo que os líquidos precisam romper ou contornar, independente de qual seja a maneira, todos os obstáculos que aparecerem para continuarem com o curso, como um verdadeiro fluxo descontrolado.

Em épocas mais antigas e tempos mais rígidos, não foi simples o rompimento de certos tabus, de modelos que chegavam ao status de sagrado, havia tradições muito rígidas que para cederem lugar ao "novo" precisavam ser invadidas, destronadas, uma verdadeira emancipação do velho que prendia a evolução da sociedade. Podemos dizer que as raízes eram sólidas, e impediam que o fluxo da modernidade seguisse o seu caminho. Não quer dizer que tudo que havia de modelo, de costumeiro na sociedade seria destruído para que houvesse um modelo completamente novo, mas quer dizer que havia certas barreiras, certos sólidos que precisavam ser limpos do caminho para que uma realidade mais moderna surgisse e aprimorasse o ambiente. Era imprescindível a ocorrência de um aperfeiçoamento, como bem nos explica ZygmuntBauman:

"Derreter os sólidos significava, antes e acima de tudo, eliminar as obrigações "irrelevantes", que impediam a via do cálculo racional dos efeitos; como dizia Max Weber, libertar a empresa de negócios dos grilhõesdos deveres com a família e o lar, e a densa trama das obrigações éticas [...](BAUMAN, 2000, p. 10) 
Assim, como mencionado, o intuito era de romper com aqueles costumes desnecessários e exagerados que prendiam a liquefação da sociedade, certos grilhões que só serviam para obstruir o movimento da evolução. Em longo prazo ocorreria a diluição de muitos modelos de vida, de comportamento, mas isso se deu de forma gradativa, foram passos pequenos e lentos para emancipar a sociedade de tantos costumes e valores que eram tão sólidos e difíceis de serem contornados.

Com o decorrer dos tempos, os antigos costumes foram sendo alterados, sendo certo que nenhum modelo foi atingido, rompido, modificado ou diluído sem que desse lugar a outros novos modelos, nessa modernidade líquida de permanentes modificações. Segundo Bauman (2000), a tarefa dos indivíduos livres pela nova forma de viver trazida pela modernidade era usar a sua nova liberdade para encontrar o nicho apropriado e ali se acomodar e se adaptar, ou seja, seguir fielmente as regras e os modelos de conduta que foram identificados como corretos e apropriados para aquele lugar; naquele tempo e naquele espaço.

Fazendo um estudo da sociedade e dos tempos líquidos segundo a teoria de Zygmunt Bauman, pode-se absorver que a modernidade se deu em seus primeiros momentos em torno do sistema, do que podemos chamar de macro, envolvendo mais precisamente espaço, política e sociedade de forma geral. Essas lutas existiram e existirão, e os tempos fluidos sempre tentarão romper com algum grilhão que possa obstruir o percurso das modificações nessas áreas, mas os tempos mais modernos desceram ao nível micro, ao lado mais particular do convívio social, se destacam as individualidades, os padrões de convivência e de interação.

O ser humano se adapta rapidamente às mudanças, mas mais rapidamente ainda ele se sente insatisfeito e desejoso de mais e mais modernidade, de mais facilidade, de mais conforto, de mais liberdade. "Mais" é uma palavra marcante diante desse tipo de estudo, assim como a palavra "velocidade".

Poderíamos mencionar inúmeros fatos e dados sobre a busca incessante do ser humano por mais poder, mais liberdade, mais conforto, mais tecnologia, e da velocidade em que nos adaptamos e nos sentimos novamente insatisfeitos, mas dentre tantos temos alguns pontos que merecem destaque. $\mathrm{O}$ homem vivia com muito pouco, a luta não era para viver bem e melhor, a luta nos primórdios da humanidade era básica, por sobrevivência. Entretanto, como ser pensante e inteligente que é rapidamente começou a lutar pelo poder, por riquezas, etc. O dinheiro unido às capacidades do homem o fez conseguir muitas coisas que facilitassem sua vida; a insatisfação permanente trouxe o ser humano às condições que se encontra nos tempos modernos ou pós-modernos; mundo de alta tecnologia, de diminuição das distancias que chegou à extraterritorialidade, instantaneidade, etc. Nos primórdios os mais privilegiados conseguiam se locomover com ajuda de animais, com a evolução foram criados os automóveis, até que o homem sonhou em voar e com os recursos financeiros unidos aos recursos intelectuais ele conseguiu e hoje pode se transportar facilmente entre continentes diferentes, ou ainda mais, estamos na era do "tele transporte". 
Nesse sentido, podemos também salientar as formas de comunicação, as facilitações nesse assunto foram gigantescas. Nossos antepassados não tão antigos assim foram privilegiados com a criação do telefone, que chegou para facilitar a comunicação com outras pessoas de cidades, estados e até países diferentes, e isso já era um avanço significativo. No entanto, a insatisfação persistia, surgiu a internet lenta, depois a rápida, as conversas de vídeo, o celular, e posteriormente o telefone móvel com internet, e hoje, andando pelas ruas podemos nos comunicar instantaneamente com quem está do outro lado do mundo através dos modernos celulares, e fazendo breve ligação com o direito brasileiro, já chegamos ao ponto de um juiz brasileiro mandar intimar uma parte de um processo pela forma mais fácil, deixando expresso em decisão que poderia ser pelo aplicativo "whatsapp". Esses são os tempos líquidos. A insatisfação não tem limites, e consequentemente a evolução também nãotem.

Sobre essa "extraterritorialidade" na modernidade, Zygmunt Bauman nos presenteia com esclarecedor comentário:

[...] o longo esforço para acelerar a velocidade do movimento chegou ao seu "limite natural". O poder pode se mover com a velocidade do sinal eletrônico- e assim, o tempo requerido para o movimento de seus elementos essenciais se reduziu à instantaneidade (BAUMAN, 2000.p.19).

O autor do Livro Modernidade Líquida menciona a palavra limite, sugerindo a instantaneidade e extraterritorialidade como se fossem o auge para a modernidade. Em seus estudos ele também sugere o que estamos vivendo no mundo atual como um suposto "fim dos tempos". É complexa a tarefa de pensar na continuidade da evolução, que principalmente nos últimos anos foi tão acelerada, haja vista as tantas vontades unidas à insatisfação dos seres humanos e também às limitações dos recursos do planeta. O autor também cita alguns termos que tem sido mencionado por ele e por outros sociólogos atuais, tais como: "fim da história", "pós modernidade", "segunda modernidade", "sobre modernidade", apesar de seu posicionamento não dar credibilidade para esses termos, e considerar a modernidade como uma constante, pois não tem limites nem controle e sempre será assim, por isso a ideia da "Fluidez". Não é viável para Bauman se falar em pósmodernidade, acreditando o sociólogo que a sociedade continuará nesse mesmo modelo de evolução, sempre buscando aperfeiçoamento e rompimento demodelos.

Para maior compreensão da ideia dos tempos líquidos, da "Modernidade líquida", o estudo foi subdividido em alguns fatores que juntos levam a sociedade a alcançar a evolução, que são eles: Emancipação, Individualidade, Espaço/tempo, Trabalho e por fim a Comunidade.

\footnotetext{
${ }^{4}$ WhatsApp - aplicativo de mensagens instantâneas disponíveis por todo o mundo e em vários idiomas, compatível com telefones móveis e também computadores.
} 


\section{A emancipação}

A ideia da emancipação nesse contexto diz respeito à necessidade de libertação da sociedade para um efetivo crescimento. É imprescindível para a libertação de qualquer estado que pessoas se encontrem, que elas queiram realmente a liberdade e que mais importante ainda que querer, que acreditem e lutem para que a emancipação ocorra. Vejamos:

"Liberdade significa literalmente libertar-se de algum tipo de grilhão que obstrui ou impede os movimentos; começar a sentir-se livre para se mover ou agir. "Sentir-se livre" significa não experimentar dificuldade, obstáculo, resistência ou qualquer outro impedimento aos movimentos pretendidos ou concebíveis" (BAUMAN, 2000,p.26)

Nesse sentido, para que ocorra a emancipação, há que existir o desejo de liberdade, em conjunto com o sentimento de "capacidade" de efetivar as mudanças necessárias que consequentemente leva os indivíduos a terem coragem de agir, de efetuar os atos necessários para que a mudança ocorra. Mas aí mora um problema, pois a maioria dos seres humanos tem medo da mudança e prefere o conhecido, a mesmice que se jogar no escuro para buscar o novo. Esse foi um problema que a sociedade encontrou de forma mais grave durante muito tempo e que ainda hoje, depois de tantas conquistas, evolução e modernidade ainda enfrenta por uma grande maioria da massa.

Digamos que é bem mais fácil se acostumar com os moldes prontos e impostos, ao que nos dizem desde crianças como o que é certo do que buscar o novo e ser cada um o autor da própria história. Essa questão é por demais complexa, pois a variedade do que cada um tem por liberdade é muito grande, ou seja,pode ser que o que determinado indivíduo busca como liberdade, como emancipação seja quase uma prisão para outro individuo que já está além e quer ir bem mais adiante ainda. A sociedade é heterogênea, e são poucos os corajosos que enfrentaram e enfrentam o mundo por seus ideais, tanto são poucos e especiais que foram marcados na nossa história, se destacaram em meio à massa que só repete o que a minoria busca. Esse é um pressuposto básico para a evolução: capacidade de agir.

\section{Bençãos da liberdade}

A liberdade, ou a emancipação é uma bênção ou será que seria uma maldição? Tendo em vista que algumas pessoas que se veem diante da solução de seus problemas podendo optar por um destino novo se esquivam de tomar as decisões adequadas e se acomodam com a situação atual, mais precisamente se escondem do que seria a solução dos "tais problemas". Essa questão é de foro muito subjetivo. Para tal reflexão, Bauman nos sugere o seguinte: "A libertação é uma bênção ou é uma maldição? Uma maldição disfarçada de bênção ou uma bênção temida como maldição?" (BAUMAN, 2000, p.28).

Em relação a essa última questão, Bauman ainda comenta que o que seria a verdade que liberta, que 
emancipa, seria a verdade que as pessoas não querem ouvir. Posto isso, percebe-se que nem todos querem, ou ainda, nem todos estão preparados para ouvir e lidar com a verdade.

Nessa senda, destaca-se a variedade de pensamentos, que podem facilitar ou dificultar a liberdade (emancipação). Depende e dependerá do querer e da capacidade de agir, e agindo, haverá também o desafio de lidar com o novo, seus ônus e bônus, arriscando o que se tem como certo (o que também é variável) ao que seria eminentemente o melhor, mas que ainda é desconhecido. "Riscos"- não são todos os seres humanos que estão aptos a isso.

\section{Individualidade}

Segundo nosso dicionário Aurélio ${ }^{5}$, o significado literal da palavra indivíduo é "aquilo que não pode ser dividido". No nosso ordenamento, a evolução deve buscar cada vez mais resguardar as individualidades, as particularidades, mesmo que essas façam parte deminorias.

De acordo com Zygmunt Bauman, considerar os membros da sociedade como indivíduos, é uma das principais características das sociedades modernas. Vejamos:

"A apresentação dos membros como indivíduos, é marca registrada da sociedade moderna".
Essa apresentação, porém, não foi uma peça de um ato: é uma atividade reencenada
diariamente. A sociedade moderna existe em sua atividade incessante de "individualização".
(BAUMAN, 2000, p.72)

Um ponto marcante e que merece ser ressaltado na sociedade moderna é o papel de destaque de cada indivíduo, dotado de deveres e obrigações, mas também com seus direitos reservados. Não há como se falar em tempos modernos, em sociedade justa, sem que se tenha preocupação em resguardar o direito de cada indivíduo que dela faça parte. A sociedade é formada por agrupamentos, por coletividade onde cada um tem extrema importância, e um dos intuitos da evolução é garantir cada dia mais o respeito aos direitos de cada indivíduo, que pode ser de tantas formas e status diferentes. O que se busca é basicamente isso, respeito às tantas diferenças que possam existir entre eles. Nossa sociedade é plural, é heterogênea, e nesse modelo que pelo menos a legislação escrita presa tanto, não há espaço para discriminações. Cada indivíduo deve ser tratado e respeitado de acordo com suas desigualdades.

Importante salientar também que, o significado de individualidade varia muito de acordo com a evolução, com o passar dos anos. O conceito que se tinha de individualidade, "de indivíduo" há 50, 60 anos é bem diferente do que se conceitua individualidade na sociedade atual. Varia de acordo com o modo de vida, status da evolução e anseios dos cidadãos para cadaépoca.

${ }^{5}$ Aurélio - Dicionário; significado das palavras em língua portuguesa. 


\section{Tempo/Espaço}

Para começar a falar de tempo relacionado a espaço, para convivência urbana, vale citar a ideia de civilidade, sendo que a civilidade se faz necessária para tornar a coabitação possível. É na união de um tempo com determinado espaço que os indivíduos têm oportunidade de se encontrarem, se agruparem, viverem em sociedade e formarem cultura e posteriormente, de acordo com as necessidades as regras que terão que ser seguidas. Pode-se dizer que os indivíduos usam máscaras em suas cenas na sociedade para tornar a convivência possível. "Civilidade" é algo parecido com diplomacia, polidez, bom senso, enfim, capacidade de seguir os moldes sociais. Nesse sentido, comenta Zygmunt Bauman:

"O que significa então dizer que o meio urbano é "civil" e, assim, propício à prática individual da civilidade? Significa, antes e acima de tudo, a disponibilidade de espaços que as pessoas possam compartilhar como personae públicas sem serem instigadas, pressionadas ou induzidas a tirar as máscaras e "deixar-se ir", expressar-se, confessar seus sentimentos íntimos e exibir seus pensamentos, sonhos e angústias. Mas também significa cidade que se apresenta a seus residentes como um bem comum que não pode ser reduzido ao agregado de propósitos individuais e como uma tarefa compartilhada que não pode ser exaurida por um grande número de iniciativas individuais" (BAUMAN, 2000.p. 123)

$\mathrm{O}$ ato de ser civil significa um ato participativo, de cooperação com a sociedade, e não significando simples fingimento, usar máscaras para disfarçar o verdadeiro eu. Não teria como viver em sociedade se não houvesse cooperação mútua dos indivíduos nesse sentido.

Ocorre que, respeitar a civilidade e os modelos conduz os indivíduos a convivência com uma uniformidade. Não é fácil ambientar-se com a pluralidade dos seres humanos. O ser humano foi moldado para viver em civilidade, a repetir o que ditam como certo. Percebe-se essa dificuldade de aceitação da massa em relação ao novo. Temos por exemplo, a luta das minorias em tentativa de afirmação na sociedade, de aceitação desta.

Segundo Bauman (2000.p.135), a capacidade de conviver com a diferença, sem falar na capacidade de gostar dessa vida e beneficiar-se dela, não é fácil de adquirir e não se faz sozinha. "Essa capacidade é uma arte, e como toda arte, requer estudo eexercício".

Em relação com o tempo e espaço, pode-se dizer que essa tendência dos indivíduos à homogeneidade tem ligação direta com as localidades, com "etnias", e também com a época em que se esteja vivendo. Isso porque, o que se considera como evolução e como modernidade em determinada "cidade", "território", pode ser considerado um absurdo, inadmissível em outrolugar.

As evoluções surgem das lutas e das necessidades de um povo que quer mudar os modos de viver, de costumes e leis, mas todas as mudanças, até os comportamentos que passam a ser diferentes ficam sujeitos à censura dos demais que não entendem ou não admitem as pluralidades, diversidades. As pessoas tem medo de algo estranho, "desconhecido" que se aproxima, o que muitas vezes as faz ficarem onde estão, na mesmice, sendo 
mero espectadores, por medo de aceitar o que chega de novo. Medo de novos empregos, novas cidades, novos governos, medo até de pensar que tem muitos direitos a exigir. O desconhecido com certeza assusta. Assim, o que sempre se vê são minorias a frente de seu tempo, lutando por mudanças que acreditam necessárias e possíveis, passando pela censura do restante da massa que segue os modelos de seu tempo e espaço.

\section{Trabalho}

Muitos acreditam que o progresso tem ligação direta com o trabalho, e que a história atual tem mais importância do que a história antiga, e também que a história de progresso que se quer amanhã é fruto da luta e do trabalho que se faz agora, "hoje". Esses posicionamentos surgem principalmente após a revolução industrial, e Zygmunt Bauman coaduna com esses pensamentos.

Assim, nessa linha de pensamento, conclui-se que o progresso não é consequência da história, mas do quanto se acredita e se produz no hoje. Sobre isso, Bauman deixaalgumas palavras importantes: "O sentido mais profundo, talvez único do progresso, é feito de duas crenças inter-relacionadas - de que "o tempo está do nosso lado" e de que somos nós que fazemos acontecer". (BAUMAN, 2000, p. 166)

Esse trecho nos deixa claro que para que a modernidade aconteça são necessários luta e trabalho. $\mathrm{O}$ tempo estará do lado de quem acredita, trabalha e faz o progresso acontecer, enfrenta qualquer tipo de censura para romper os moldes da sociedade.

Acreditar é importante para tentar o progresso, pois a luta envolve riscos. Quem trabalha e luta pelo progresso não tem garantias de que as conquistas o deixarão mais feliz, mas se vê a necessidade de mudanças e acredita que sejam possíveis e favoráveis vai fazer o que for necessário para efetivá-las.

Segundo Bauman, (2000, p.169), o progresso e a modernidade podem ser trabalhados, aperfeiçoados, para serem mais satisfatórios do que são. O progresso é como uma tarefa, uma batalha, não é algo determinado, mas algo feito, envolvendo o trabalho. Essa tarefa é incompleta, e necessita incessantemente de novos cuidados e esforços. O progresso não é uma questão transitória que leva eventualmente a uma "perfeição", mas é um desafio e uma necessidade perpétua, talvez sem fim, o verdadeiro significado de se permanecer vivo e bem.

O progresso parece algo um pouco distante e tal sensação pode ser causada pela individualidade acentuada cada vez mais. As necessidades são diversificadas e as tarefas para alcançar o progresso variam bastante devido ao pluralismo.

\section{Comunidade}

Na sociedade, as comunidades sempre tiveram e têm papel muito importante; papéis favoráveis e outros desfavoráveis à evolução. 
Tendo em vista que, no meio dessa avalanche que é a evolução, valores tão diferentes de acordo com cada espaço, cada lugar em que se vive, os indivíduos estão em local confortável quando se encontra em meio a grupos de pessoas que coadunam de mesma cultura, pensamentos, ideologias. No entanto, no que tange à evolução, tais comunidades podem se tornar empecilhos, como já houve tantos casos, quando alguns grupos se unem de forma contrária ao pensamento da massa.

Para que o Estado evoluísse ao status da atualidade, não foram poucas as comunidades que tiveram que ser suprimidas, por exemplo, a imposição de língua universal ao invés de línguas diferenciadas de acordo com etnias, agrupamentos, etc.

\section{Associação da teoria da modernidade líquida com os desafios da hermenêutica e aplicação justa do direito na atualidade}

A teoria da Modernidade líquida foi desenvolvida, como já relatado, para explicar de forma metafórica o que aconteceu e continua acontecendo com nossa sociedade fluida, de mudanças rápidas e sem controle, de moldes que se modificam descontroladamente, de formaimprevisível.

O direito como uma ciência social sempre acompanha, ou pelo menos tenta acompanhar o ritmo das mudanças e o sentimento social que sempre carece de inovações, decisões mais amplas, que busquem solucionar os novos conflitos. Existem algumas searas jurídicas, que ultrapassaram todas as previsões de evolução e a cada dia mais incumbem ao judiciário decisões mais complexas, desafios grandiosos aos julgadores que nem sempre estão amparados por legislações compatíveis com os casos concretos, pois a grande maioria da legislação só é elaborada, sancionada e publicada após a preexistência de alguns problemas sociais. Existem também casos em que há legislação para o assunto, mas o problema concreto a ser julgado já ultrapassa muito a previsão legal, e que faz o julgador que não pode se eximir de aplicar a lei usar os princípios fundamentais e o bom senso para decidir o litígio. Isso é a sociedade, que não se desvincula do judiciário (Direito) que é o controlador do convívio social.

Posto isso, é viável o entendimento da teoria social da modernidade líquida, que explica muito bem o que acontece com o direito que é social, que existe para a sociedade, que também não é e jamais poderia ser estável. Os modelos mudam e o direito cronologicamente é modificado, a "conta gotas". Da mesma forma que a evolução da sociedade quis e quer sempre romper regras morais e costumes desnecessários, o direito também se modifica para contornar barreiras desnecessárias e que são grilhões que impedem a melhoria, que impedem o pluralismo, o direito das minorias, etc. Modernidade líquida da sociedade e modernidade líquida do direito que é instrumentalizado através de seus princípios para acompanhar o sentimento social. Seria difícil desvincular o direito da sociedade, pois um existe para o outro.

Destaca-se na fluidez social, fluidez do direito, e nos desafios em busca de decisões mais justas a 
"hermenêutica", que é uma interpretação mais ampla, que considera um conjunto de fatores, princípios e momento atual da sociedade. Essa questão será esclarecida de forma mais completa em capítulopróprio.

\section{Modernidade líquida e a questão da sustentabilidade}

As ideias com relação à sustentabilidade começaram a ser divulgadas no ano de 1960. Começou a se pensar em desenvolvimento da economia com respeito ao meio ambiente e essa ideia representa desenvolver-se, usando os recursos de hoje, mas pensando no amanhã, haja vista que as necessidades do homem são infinitas e os recursos não.

Não há como na atualidade pensar em evolução e modernidade sem pensar em sustentabilidade, pois as preocupações nesse sentido têm aumentado devido a dados alarmantes de desgaste ambiental.

Em termos de legislação, desde a Constituição do Império de 1824 já foi feita pequena menção a garantias ambientais, passando pela Constituição de 1934, carta de 1937, constituição de 1946, Constituição de 1967 e carta de 1969, todas com algumas garantias ao patrimônio paisagístico e cultural, mas nunca com legislação de proteção ao meio ambiente especificamente. Logo, na Constituição da República de 1988, esta já pôde ser considerada por muitos uma "Constituição Verde" ambiente, inclusive em capítulo próprio da Constituição da República, colocando na nossa lei maior a importância de se viver em harmonia com a natureza.

Após a Constituição de 1988, várias leis foram criadas para regulamentar as garantias constitucionais nesse sentido, ao total somam 18 leis. Algumas criando órgãos como a lei que criou o Ibama (lei 7.735/89), a lei que criou o Ministério do meio ambiente (lei 8.746/93), a que criou a Agência Nacional de Águas - ANA (lei 9.984/2000), e outras que criaram algumas garantias específicas. Entretanto, mesmo após a Constituição de 1988 trazer em seu texto garantias mais específicas e terem sido criadas leis regulamentadoras ainda é insuficiente para solucionarem a questão, pois os relatos são de que falta atuação consistente de todos os órgãos em relação ao meio ambiente. Os órgãos atuam, mas deixam muito a desejar.

Em tese de mestrado da UNB (Universidade de Brasília), a mestranda Marina Salim Pires fez no ano de 2009 um estudo sobre a Modernidade (pós-modernidade) em seu trabalho, com relação direta com a sustentabilidade. De acordo com esse estudo, e com os autores que o basearam, um dos principais objetivos do projeto de modernidade, seria estabelecer ordem e progresso por meio da razão, e a ciência seria o meio pelo qual o projeto de modernidade obteria êxito, ou seja, evolução inteligente, pensando no hoje e no amanhã. Para que

\footnotetext{
${ }^{6}$ Constituição verde - nome dado para muitos especialistas à Constituição de 1988, pelo fato de ser considerado um dos modelos legais mais abrangentes na área e por enfatizar no texto a necessidade de convivência harmoniosa com a natureza.

${ }^{7}$ PIRES, Marina Salim, Turismo e pós Modernidade: Teoria, cultura e sustentabilidade. 2009.p.40- Dissertação de mestrado -

UNB (Universidade de Brasília), Brasília,2009.
} 
ocorra a modernização há necessidade de uso dos recursos culturais e ambientais, mas se não racionalizados eles se esgotam, daí a modernidade traria mais malefícios do que benefícios. Infelizmente, na era dos tempos líquidos, se pensou pouco em desenvolvimento sustentável. Diante das calamidades da atualidade se falam mais sobre o assunto. Existem leis, mas as políticas relacionadas ao meio ambiente ainda não são suficientes, principalmente porque a efetiva sustentabilidade não depende apenas de governo e legislação, mas consciência de cada indivíduo, de educação ambiental.

Houve o tempo em que o homem começou a se sentir o dono da natureza, e passou a transformá-la de maneira cada vez mais excessiva para que conseguisse evoluir. A natureza foi transformada em um dos objetos de produção, aliás, objeto imprescindível principalmente após a revolução industrial, e foi um tempo muito grande que foi somente usada sem que se pensasse em conservação. Hoje, em consequência disso, temos dados alarmantes de escassez de muitos recursos naturais, e preocupações um pouco tardias que tentam remediar o tamanho desgaste que já ocasionado. Este é um dos pontos negativos da modernidade, pois se percebe uma relação muito distante entre o ser humano e o meio-ambiente, sendo que o primeiro necessita deste último para a sobrevivência.

Os estudiosos, assim como a autora da tese mencionada acima, acreditam que os tempos pós-modernos, que são os atuais, ou "fim dos tempos" como chega a mencionar Bauman (2000.p.18), têm ligação imensa com a questão da sustentabilidade. Apesar de já estar sendo trabalhada desde o ano de 1960, e com esse termo sendo usado desde 1980, foi nos últimos anos que ganhou mais evidência e causou maior preocupação na população que tem percebido que tem que se conscientizar. Logo, se vê que é na era mais moderna da história que os danos começaram a ser percebidos em gravidade grande.

A fluidez social nem sempre respeitou o meio ambiente, e atualmente, temos enfatizado a necessidade de viver em harmonia com a natureza, ou seja, a evolução só ocorrerá de verdade se for de maneira racional. Caso contrário, poderemos considerá-la uma maldição disfarçada de bênção, como sugere Bauman (2000).

\section{HERMENÊUTICA E OS PRINCÍPIOS BASILARES NA BUSCA DE INTERPRETAÇÃO QUE GARANTA DECISÕES JUDICIAIS MAIS JUSTAS EM MEIO A TANTAS MUDANÇAS}

A interpretação do direito consiste em fixar uma relação jurídica, seria o estudo de uma norma já existente para adequá-la a determinada situação, para possibilitar a aplicação do direito.

Sobre interpretação, R. Limongi França, citando palavras de Fiori nos deixa o seguinte conceito: "Interpretação da lei é operação que tem por fim, fixar uma determinada relação jurídica, mediante a percepção clara e exata da norma estabelecida pelo legislador." Fiori (apud R. Limongi França, 2008.p.21). 
Diante do conceito mencionado, percebemos a interpretação um mecanismo muito adstrito às leis, diferente da "hermenêutica jurídica", que é mais ampla, que sistematiza outros fatores envolvidos para facilitar a própria interpretação.

Limongi França (1988) nos esclarece que tanto a interpretação quanto a hermenêutica não podem se restringir aos estritos termos da lei, pois conhecidas são as suas limitações para bem exprimir o direito. Assim sendo, é ao direito que a lei exprime que devem endereçar tanto a interpretação quando a hermenêutica a fim de alcançar aquilo que o legislador não conseguiu ao elaborar a norma, mas nunca fugindo do fim para o qual a norma existe.

Logo, tanto a interpretação quanto a hermenêutica se baseiam no direito, na norma que se tem para cada caso. No entanto,após esses pontos que diferenciam as duas maneiras que na realidade se completam, destaca-se o papel da hermenêutica que faz parte da ciência jurídica, e que sistematiza o direito como um todo para uma melhor interpretação da norma já existente, pode-se dizer que a hermenêutica é um conjunto de todas as normas de interpretação.

Seguindo o que nos deixa R. Limongi França sobre interpretação e hermenêutica existem algumas regras que devem ser seguidas, que são: regras legais, regras científicas e regras dejurisprudência.

Regras legais seriam as regras que existem no próprio ordenamento jurídico para nortear a interpretação e hermenêutica. Temos como exemplo as disposições da LICC (Lei de introdução ao Código civil) sobre o assunto em seus artigos $4^{\circ}, 5^{\circ}, 6^{\circ}$ e 7o; também temos como exemplo uma regra de hermenêutica trazida no texto da Constituição da República no art $5^{\circ}$ que diz "que o juiz, na aplicação da lei, atenderá aos fins sociais a que ela se destina e às exigências do bem comum".

Regras cientificas ${ }^{8}$, que trazem mecanismos que devem ser seguidos para uma melhor interpretação e hermenêutica: Como exemplo, pode-se mencionar que: Nenhuma expressão é irrelevante no texto de uma lei; que a ementa de uma lei facilita sua inteligência, que o caso omisso na letra da lei se compreende na disposição quando há razão mais forte, etc.

As regras de jurisprudência, também são regras gerais e que buscam uma lógica e coerência na hermenêutica, segundo o autor R. Limongi França (1988), grande parte destas regras foram deixadas por Washington de Barros Monteiro9. Deixa com elas questões amplas que devem ser observadas, restrições que devem ser seguidas e o cuidado que o interprete tem que ter para não agir de forma contraditória ouabsurda.

Essas regras mencionadas são quesitos básicos, porém imprescindíveis para uma eficiente interpretação e aplicação do direito.

\footnotetext{
${ }^{8}$ Regras científicas deixadas por Carlos de Carvalho. Consolidação Leis Civil. 1899 (apud França, R. Limongi. 1988)

${ }^{9}$ Washington de Barros Monteiro - Jurista brasileiro, falecido no ano de 1999, ex professor de Direito na Faculdade de Direito da USP (universidade de São Paulo) e autor de obras como Curso de Direito Civil.
} 
O autor Limongi França, nos deixa em sua obra sobre hermenêutica algumas regras de própria autoria para a hermenêutica jurídica eficiente, que são:

I. O ponto de partida da interpretação será sempre a exegese pura e simples dalei;

II. Num segundo momento, de posse do resultado dessa indagação, o intérprete deverá reconstruir o pensamento do legislador, servindo-se dos elementos lógico, histórico esistemático;

III. Num terceiro momento, cumprir-lhe-á aquinhoar a coincidência entre a expressão da lei e a descoberta auferida da intenção do legislador;

IV. Verificada a coincidência estará concluído o trabalho interpretativo, passando-se desde logo à interpretação da lei;

V. Averiguada, porém, a desconexão entre a letra da lei e mens legislatoris devidamente comprovada, o interprete aplicará esta e não aquela;

VI. Se na indagação da mens legislatoris, os resultados forem diversos, cumprirá preferir aquele que seja mais consentâneo com a índole natural do instituto que a norma regula, bem assim como as exigências da realidade social e do bem comum;

VII. Se os resultados viáveis forem ainda insuficientes, em virtude de defeito ou omissão da lei, deverá o intérprete recorrer à analogia, e, quando inexequível,às formas suplementares de expressão do direito;

VIII. No uso dessas outras formas, mutatis mutandis, será mister agir de forma semelhante ao da interpretação da lei, procurando, inicialmente descobrir na forma exterior a exata expressão da regra supletiva, e, em seguida, a sua conformidade com a intenção do órgão fautor da regra;

IX. Na utilização das formas suplementares de expressão do direito, necessário se fará obedecer à hierarquia prevista na lei: costume (que inclui jurisprudência e standard jurídico), princípios gerais de direito, e por fim, demais formas como doutrina, direito comparado, etc.;

X. Quando, a despeito de todas essas providências, houver ainda falta de elementos, com base nos princípios gerais de direito (do sistema positivo, direito natural e da doutrina consagrada),o interprete poderá construir, com vistas postas na realidade sócia jurídica, a norma especial própria ao caso. "(FRANÇA, Limongi. 1988).

A hermenêutica se realiza quanto o aplicador do direito além de unir o caso que carece de decisão às disposições legais, analisa também o contexto social e todos os fatores que envolvem o caso, assim, o uso das regras mencionadas é de grande importância para a interpretação que é sistematizada pela hermenêutica. A hermenêutica faz parte da ciência jurídica, consiste em absorver o direito que está além das leis que estão nos textos legais, observa o direito como um todo, de maneira racional, pautado na lógica e também no bom senso. 
Em tempos de modernidade líquida, não há como aplicar o direito sem essa análise mais ampla que usa as regras de hermenêutica unidas à realidade dos fatos. Tal questão é um desafio ao judiciário, que deve aplicar o direito de forma a acompanhar as necessidades da sociedade, mas sem fugir do fim para o qual a lei existe e foi criada. Amplitude, porém com proporcionalidade.

\section{Uso dos princípios para realização da hermenêutica}

Estamos em uma era de nova interpretação da Constituição Federal, que é chamada de pós-positivismo ou neoconstitucionalismo. Neste novo quadro é desenvolvida uma forma racional de interpretação, que é pautada muito mais na razoabilidade e na prudência do que no direito formal.

Em artigo disponibilizado no site jusnavigandi.com, os autores Argemiro Cardoso Moreira Martins e Luiz Henrique Urquhart Cademartori comentam essa nova realidade na hermenêutica constitucional:

"Sob tal perspectiva, a categoria central da validade normativa estaria fundamentada não mais sob a ideia de uma estrutura normativa lógico-dedutiva que principia na constituição e finda na decisão judicial, a partir do qual tudo deriva mediante processos de subsunção formal, e sim como centro ao qual tudo deve convergir, a partir dos múltiplos fatores da realidade social, vale dizer, como centro a ser alcançado e não do qual se devepartir" ${ }^{10}$

O uso dos princípios na hermenêutica e na aplicação do direito permite que sejam proferidas decisões pautadas em direitos fundamentais, com escopo sempre de decisões mais justas. A sociedade é fluida e os valores também são muito imprecisos, o que dificulta o trabalho do interprete que deve agir com muita ponderação.

\section{Robert alexy e a teoria de direitos fundamentais e princípios}

De acordo com Robert Alexy ${ }^{11}$, os princípios, que juntamente com as regras são espécies de normas, tem escopo de otimização, tem caráter mais amplo do que as regras que deixam claras em seu texto tudo que é ou não possível. Dispõe ainda o autor que as possibilidades jurídicas são determinadas pelos conflitos de princípios e regras que entram em colisão.

O autor usa a palavra conflito para denominar a desarmonia entre as regras; já para os princípios ele usa a expressão colisão, pois segundo ele é nessas características que se tornam mais evidentes as diferenças entre os dois tipos de normas.

Como mencionado, as regras já trazem em seu texto o que será possível e o que não será, e por isso, quando duas regras entram em conflito, terá que ser colocada uma exceção entre elas, ou então uma delas terá que

${ }^{10}$ MARTINS, Argemiro Cardoso Moreira; CADEMARTORI, Luiz Henrique Urquhart. Hermenêutica principiológica e ponderação de direitos fundamentais: Revista Jus Navigandi, Teresina, ano 12, n. 1453, 24 jun. 2007. Disponível em: <http://jus.com.br/artigos/9952>. Acesso em: 15 maio 2015.

${ }^{11}$ ALEXY, Robert. TEORIA DOS DIREITOS FUNDAMENTAIS. Malheiros Editores.1985 (Tradução brasileira de Virgílio Afonso da Silva). 
ser considerada inválida, sendo a solução mais complexa por causa da formalidade. No que tange aos princípios, "a colisão" é solucionada de forma diferente, um dos princípios deverá ceder ao outro. Nos casos dos princípios é estabelecida uma precedência, um sopesar diante do caso concreto. Em determinado caso, um princípio pode se sobressair em relação ao outro, e em outro caso, pode ser que o princípio que teve menos peso na tomada de decisões anteriores se sobressaia em relação a outros. Aparentemente pode haver algum princípio de maior peso, mas na realidade, tudo dependerá da proporção da necessidade e do caso, não havendo então princípio mais importante nem absoluto.

De acordo com Alexy (1985), nesses casos em que existe colisão entre os princípios, há uma tensão entre o Poder estatal de garantir uma solução adequada e indivíduo que tem constitucionalmente garantido seu direito, e cuja proteção a lei também obriga o Estado. Nesse caso, não existirá precedência absoluta de nenhum desses deveres, por nenhum deles gozar de prioridade. O judiciário terá que sopesar os interesses conflitantes.

Essa é a luta do Estado na solução dos conflitos: colocar os interesses na balança e garantir decisões racionais garantidoras dos direitos fundamentais protetores dos direitosfundamentais.

Ao explicar sua teoria sobre princípios, Robert Alexy enfatiza a máxima da proporcionalidade, por haver tamanha conexão entre os dois assuntos:

"[...]há uma conexão entre a teoria dos princípios e a máxima da proporcionalidade. Essa
conexão não poderia ser mais estreita: a natureza dos princípios implica a máxima da
proporcionalidade, e essa implica aquela. Afirmar que a natureza dos princípios implica a
máxima da proporcionalidade significa que a proporcionalidade, com sua três máximas
parciais, da adequação, da necessidade(mandamento do meio menos gravoso) e da
proporcionalidade em sentido estrito(mandamento do sopesamento propriamente
dito, decorre logicamente da natureza dos princípios, ou seja, que a proporcionalidade é
deduzível desta natureza." ALEXY, Robert (1985.p.117).

Como mencionado, há ligação estreita entre a máxima da proporcionalidade e os princípios para solução dos conflitos, segundo o autor em questão. A análise proporcional é imprescindível para efetuar o sopesamento entre princípios e consequentemente decidir conflitos de interesses. Uma decisão para que seja justa tem que ser razoável e proporcional, e proporcionalidade quer dizer possibilidade de relativização das possibilidades do direito.

\section{Proporcionalidade/razoabilidade}

A Constituição da República de 1988 é uma Constituição baseada em princípios, alguns declarados formalmente na própria letra da Lei maior e outros que implicitamente fazem parte do ordenamento. Os princípios de direito precisam ser estudados para se falar de qualquer questão sobre o assunto, principalmente na era do neoconstitucionalismo, onde as decisões são pautadas muito mais nos princípios do que nas regras formais. 
Aplicar o direito perante a modernidade líquida e proferir decisões realmente justas implica aos julgadores atuar pautados em princípios, mas em bom senso também. Um julgamento pautado somente em regras seria muito previsível e rígido, já um julgamento pautado somente em princípios seria muito flexível. Por isso, é imprescindível a ponderação.

Razoabilidade advém de razão, equilíbrio entre dados e conhecimentos. Proporcionalidade e razoabilidade são usados basicamente como sinônimos para a maioria dos doutrinadores como Maria Zanella de Pietro e Celso Antônio Bandeira de Melo ${ }^{12}$, pois defendem que uso da razoabilidade seria meio para se chegar ao fim que seria a proporcionalidade. Existem posições divergentes, alegando inclusive a existência de uma lei brasileira que diferencia os dois princípios, Lei n. 9.784/99.

Como já anteriormente mencionado, a proporcionalidade, que se identifica com a razoabilidade, segundo a própria teoria de Robert Alexy se divide em três elementos, que são eles: adequação, necessidade e proporcionalidade em sentido estrito.

No que tange à adequação, teria a ver com a finalidade de alcance dos objetivos que são pretendidos; a necessidade seria as decisões terem que restringir o menos possível os direitos dos indivíduos, e por fim, a proporcionalidade em sentido estrito seria a necessidade fundamental do sopesamento entre os princípios, uma proporcionalidade entre os meios e os fins.

Para os defensores da dicotomia entre os princípios da razoabilidade e proporcionalidade, a razoabilidade também se divide em subprincípios, que seriam eles equidade, equivalência e congruência. Equidade seria na adequação da norma ao caso do indivíduo e possibilidade de se abrir mão de determinada norma e decidir em princípios através de razoabilidade caso necessário; congruência seria o nome dado à relação que a decisão razoável tem que ter com o contexto social, pois a decisão não deve ficar além do que a sociedade necessita, e também deve tomar cautela para não ficar aquém do que o contexto social tem necessitado; equivalência por fim, seria uma certa simetria entre o princípio e/ou regra adotados e o fim a que se destinam.

Em artigo disponibilizado no site jusnavigandi.com, o especialista em direito público, Caio Vinícius Carvalho de Oliveira ${ }^{13}$ relata sobre as diferenciações entre os dois princípios, de acordo com os posicionamentos que são favoráveis à dicotomia:

"[...] a distinção entre proporcionalidade e razoabilidade consiste no fato de que o primeiro está relacionado ao critério de meio e fim, na medida em que o meio adotado deverá obedecer aos critérios de adequação, necessidade e proporcionalidade em sentido estrito para que a exigência de realização do fim seja atingida. Em contrapartida, na opinião do autor

\footnotetext{
${ }^{12}$ PIETRO, Zanela de; MELLO, Celso Antônio Bandeira de (apud Princípio da proporcionalidade versus razoabilidade, Diego Bruno de Souza Pires, UNEB (Universidade Estado da Bahia), disponível em www.ambitojuridico.com.br-acesso de 17.05.2015) ${ }^{13}$ OLIVEIRA, Caio Vinícius Carvalho de. Distinção entre razoabilidade e proporcionalidade. Revista Jus Navigandi, Teresina, ano 17, n. 3337,20 ago. 2012. Disponível em: <http://jus.com.br/artigos/22438>. Acesso em: 17 maio 2015.
} 
o segundo significa a relação de equivalência entre duas grandezas, sendo a razoabilidade como diretriz que exige a relação das normas gerais com as individualizadas do caso concreto ou como diretriz que exige uma vinculação das normas jurídicas com o mundo ao qual elas fazem referência."

No Brasil, ainda não existem posições concretas de separação entre os princípios da proporcionalidade e razoabilidade, nem mesmo pelo Supremo Tribunal Federal que faz certa confusão entre os dois, justamente por haver quem defenda a sinonímia e quem defenda a dicotomia.

Postas as considerações sobre as possíveis diferenciações e alguns posicionamentos de que tratamos de um mesmo princípio, o que se destaca é que é ou são os princípios que mais são importantes para a ponderação entre regras, princípios e casos concretos em determinada realidade social que sempre depende do tempo. É através de proporção e razoabilidade que se mede e controla decisões judiciais, atos administrativos e se evita caprichos, faltas ou exageros por parte de quem aplica odireito.

\section{Da dignidade da pessoa humana}

Já foi mencionado no presente estudo o fato de que decisões que são pautadas em princípios são geralmente garantidoras de direitos fundamentais, buscando decisões equânimes, equivalentes, ponderadas e que buscam o bem comum da sociedade, o que é dever doEstado.

Dentre os direitos fundamentais, enfatiza-se a dignidade da pessoa humana, que é o centro de alguns outros direitos e de vários outros princípios. É o fundamento dos direitos fundamentais. Na nossa Constituição da República de 1988 está formalmente explicitado no art. 1º, inciso III. A análise dos outros direitos fundamentais e de princípios que advém da Constituição é baseada no direito fundamental da dignidade da pessoa humana.

A dignidade da pessoa humana como direito fundamental, tem escopo de proteger os seres humanos de qualquer forma de arbitrariedade e desrespeito, principalmente no que diz respeito às decisões do judiciário e atos da administração pública. É intimamente ligado aos direitos humanos e no que tange à hermenêutica, ajuda o interprete a ponderar em seu desafio, haja vista ser esse direito fundamental centro de outros direitos e princípios. Dignidade é uma qualidade do ser humano e é considerada inalienável eirrenunciável.

Dessa forma, destaca-se que a dignidade da pessoa humana significa o cerne dos direitos fundamentais, deve ser respeitada na hermenêutica, nos julgados, enfim, na aplicação do direito, cabendo também ao Estado não admitir o desrespeito deste que é um direito de cadaindivíduo.

\section{Princípio da isonomia}

Dentre os princípios que dão base a várias decisões que estão além da formalidade do direito, um dos mais importantes é o princípio da isonomia/igualdade, consagrado formalmente na Constituição da República de 
1988 no seu art. $5^{\circ}$ caput. Ele é base para decisões democráticas, ao tratamento equânime que pode até tratar as pessoas diferentemente (ações afirmativas, por exemplo), mas tem que existir justificativa muito justa e razoável, para igualar os seres humanos em direitos e oportunidades.

Esse princípio é fundamental na luta de combate às discriminações, para a aceitação do pluralismo, pois tenta confirmar que todos são mesmo iguais perante alei.

\section{MODERNIDADE LÍQUIDA E O DIREITO DE FAMÍLIA - COMO OS APLICADORES DO DIREITO TEMM ENFRENTADO OS TANTOS DESAFIOS}

A ideia central do presente estudo é a Teoria da Modernidade Líquida, desta metáfora que explica muito bem a realidade da leveza dos nossos tempos que sem controle seguem novos caminhos, da fluidez social que rompe os obstáculos, da evolução sem limites que faz com que o ser humano não se contente com nada durável.

Logo, para problematização dessa teoria associada aos novos desafios do direito, foi escolhida a seara do direito de família, que tem sido um dos melhores exemplos para que possamos mensurar a fluidez da sociedade e do direito. Todos os parâmetros, "padrões" imagináveis foram rompidos nessa área, deixando ao intérprete do direito grandes desafios no dia a dia para a solução de tantos novos casos que surgiram e continuam aparecendo na sociedade e no judiciário.

O direito de família, diferente de outras áreas do direito, é muito mais ligado a valores do que ao que temos como direito formal. O Direito de família ainda é considerado como de natureza privada, mas com tendência à publicitação de acordo com especialistas. A essa seara, é incumbido o dever de regulamentar e coordenar as relações existentes na sociedade, relações que se modificaram muito nas últimas décadas.

O próprio autor Zygmunt Bauman, em uma passagem de seu livro Modernidade líquida menciona um comentário de Ulrick Back em uma entrevista dada a Jonathan Rutherford, no que tange às radicais mudanças na instituição familiar, Vejamos: "o que é mesmo uma família hoje em dia? O que significa? É claro que há crianças, meus filhos, nossos filhos. Mas, mesmo a paternidade e a maternidade, o núcleo da vida familiar, começam a se desintegrar nos divórcios[...]"14

Os modelos de família foram mudados, e atualmente, qualquer agrupamento em que exista afetividade pode ser considerado como uma família.

Diante do cenário complexo, os casos concretos que tem buscado soluções da justiça também são: Quem pode se casar? Quem pode adotar? Quem terá direito à guarda dos filhos e à pensão? Até que ponto chega a responsabilidade de avós? Licença maternidade pode ser estendida a um homem? O que pode ser considerado como família: dois pais e um filho? Duas mães e um filho? Ou apenas um casal heterossexual com seus filhos?

${ }^{14}$ BECK, Ulrich apud BAUMAN, Zygmunt. Teoria da Modernidade Líquida, Zahar, Rio de janeiro. 2000.p.13 
São inúmeras as questões e as possibilidades, e os critérios e soluções são pautados em princípios, nas garantias fundamentais, no bem estar das pessoas envolvidas, principalmente quando envolve direito de menores. Para melhor entendimento dos novos conflitos e dos desafios ocasionados pela solução deles, serão comentadas algumas questões importantes que auxiliam na razoável aplicação dodireito.

\section{Da mediação no direito de família}

A mediação é uma nova possibilidade, pode-se dizer que seja uma espécie de ferramenta para solução de conflitos. É sabido que o judiciário está abarrotado de processos que delongam por anos e mais anos, e no caso da mediação, é escolhida uma terceira pessoa que irá imparcialmente promover a comunicação entre as partes envolvidas, buscando solução do caso e ainda, tentando harmonizar a relação entre as pessoas, o que é muito favorável quando se trata de casais, familiares, na maioria das vezes com filhos envolvidos, etc.

O direito de família que considerado tradicional, enfatiza as questões patrimoniais nas soluções dos casos, mas na atualidade, tem sido destacada a necessidade de dar atenção às questões psicológicas, psicossomáticas e mais voltadas para a situação social das partes envolvidas em um litígio. Por isso, a mediação no direito de família surge como facilitador da comunicação entre as pessoas, para que se evite traumas, transtornos, e ainda, agilizar a solução dos conflitos que poderiam demorar anos e anos para serem solucionados.

No Brasil, existe no Congresso Nacional, desde o ano de 1996, um projeto de lei que insere a Mediação formalmente no ordenamento, fazendo modificações no CPC e ainda na lei que disciplina a arbitragem. A mediação, nesse caso, seria inserida como método de caráter preventivo e natureza consensual (PL no 4827b/1988). Fala-se em mediação no Brasil desde o ano de 1980, mas é uma prática que ainda não possui o devido reconhecimento jurídico. Para que partes de um processo recorram a tal possibilidade, há necessidade de consenso e voluntariedade.

\section{Interdisciplinaridade}

Interdisciplinaridade significa a interação entre diversas disciplinas, e no direito de família significa um instrumento para que se execute uma atividade de relacionar áreas e fazer interconexões de conhecimentos para que sejam solucionados os problemas contemporâneos. As relações entre os conhecimentos podem ser de forma a complementar, podem ser divergentes ou ainda convergentes.

Em artigo para a revista jurídica Cesumar, Diocélia da Graça Mesquita Favaro ${ }^{15}$ discorre sobre o tema interdisciplinaridade, trabalho que inclusive ressalta a importância dessa união de vários conhecimentos ao

\footnotetext{
${ }^{15}$ FAVARO, Diocélia da Graça Mesquita. Interdisciplinaridade, sua importância na formação jurídica e sua aplicação ao Direito de
} família. Revista Cesumar. V.5. N.1.p 209-232,2005. 
Direito de família. A autora explicita o que seria e a importância da interdisciplinaridade. Vejamos: “[...] todo conhecimento mantém um diálogo permanente com outros conhecimentos, que pode ser de questionamento, de confirmação, de complementação, de ampliação, de iluminação de aspectos não distinguidos."

A interdisciplinaridade ocorre quando há determinada interação entre duas ou mais disciplinas do direito ou às vezes até indiretamente ligado a ele, como é o caso da psicologia, serviço social, etc. A interdisciplinaridade implica em uma comunicação entre naturezas diferentes de conhecimentos, com escopo de facilitação e melhoramento da qualidade dostrabalhos.

No âmbito jurídico, há uma diversidade muito grande de conhecimentos, o que leva a necessidade dessa troca entre áreas conexas. Os profissionais assim têm possibilidade de conhecimento mais profundo das situações e passa a entender as intersubjetividades.

No direito de família, tem predominado a questão da efetividade, que é considerado um elemento metajurídico, e com base nesse critério que possibilitou a elasticidade das relações de família, se justifica necessidade de uso de disciplinas conexas, como a psicologia, pois a questão afetiva é de cunho psicológico e o jurista trabalhará melhor nas questões de família se entender sobre as outras disciplinas que estão além do que ele exerce. A psicologia aqui é um exemplo, pois são diversas as conexões dentro da própria área jurídica que podem ser realizadas para otimização da atuação da justiça.

\section{Transdisciplinaridade}

Se realizarmos a análise da palavra transdisciplinaredade pelo seu significado se obtém de logo a ideia de disciplinas que estão ao mesmo tempo em espaços diferentes.

Transdisciplinaridade então seria uma união da ciência e dos vários ramos de pesquisa, comunicação entre as tantas áreas. Nesse caso, cada disciplina mantém sua autonomia, mas cada uma delas participaria de uma grande unidade de um conjunto mais complexo.

Não há como se falar em ligação aleatória de todas as pesquisas, pois existe um pilar que tem que ser seguido que é o da realidade, que em outras palavras significa que deve haver alguma conexão entre os ramos que vão se unir. Tem que haver uma relação mesmo que indireta entre asáreas.

A diferença entre interdisciplinaridade e trandisciplinaridade seria que na primeira a soberania das disciplinas sofre uma relativização para que se unam duas ou mais disciplinas e geralmente se forma uma nova forma de pesquisa. Na última, não há formação de nova disciplina, há uma comunicação para que o estudo de todas juntas facilite a compreensão do mundo quevivemos.

No direito, principalmente direito de família, transdisciplinaridade é a admissão de polissistemas de disciplinas, de ciências, possibilitando a conexão da ciência jurídica com outras áreas da sociedade. $\mathrm{O}$ direito deve 
ter visão e atitude transdisciplinar, pois as decisões judiciais afetam bastante praticamente todos os ramos da sociedade. Decisões do judiciário sem analise de outros sistemas e ciências seria muito carente e insatisfatório.

Em artigo sobre o tema, o autor Eduardo SeinoWiviurka ${ }^{16}$ esclarece sobre a contribuição que a visão transdisciplinar pode dar ao direito, e que o direito é transdisciplinar: "[...] o direito é importante demais para ser deixado somente nas mãos dos juristas. Ademais, por centralizar todas as questões, independente de natureza sociológica, econômica, morais, etc.- é por excelênciatransdisciplinar"

Acrescenta ainda o autor que o paradigma do direito, que seria segundo ele o direito positivado, estaria em crise e que esta crise possibilita e necessita da transdisciplinaridade, onde diversas áreas, onde o polissistema entra em conexão para melhorar a atuação do judiciário.

No que tange ao direito de família não é diferente, muito pelo contrário, pois as decisões relacionadas a esta área interferem demais na sociedade e na vida dos administrados, sendo impossível na atualidade proferir decisões satisfatórias sem visão de outras áreas que esclareçam e agreguem conhecimentos ao direito.

\section{A psicologia nas varas de família}

As maiorias dos casos que chegam às varas de famílias são complexos, alguns envolvendo dor, mágoa, frustrações, sentimentos delicados que afetam os seres humanos, ressaltando que cada ser humano é o resultado de sua base educacional e psicológica e que cada indivíduo responderá de maneira distinta aos golpes de crises familiares, salientando ainda que nas varas de famílias podem estar envolvidas desde crianças que não nasceram até pessoas da terceira idade.

A psicologia na seara jurídica, principalmente nas varas de família, tem papel de cognição das mentes envolvidas, estuda as condições de vida, as atitudes das partes, ajuda na conciliação e evita maiores traumas, podendo agregar muito às decisões do juiz. O próprio juiz, dotado da autoridade que tem, e por não ter que dominar todas as áreas pode requerer quando julga necessária uma perícia psicológica para conhecer melhor a situação e formar seu convencimento para que seja tomada a decisão correta.

O psicólogo poderá também transcender a função de perito e chegar a ser uma espécie de mediador, escutando e acolhendo as partes envolvidas no processo. Dentre as ações que podem ser subsidiadas pelas perícias e mediação de psicólogos destacam-se ações de guarda, tutela, curatela edivórcios.

\footnotetext{
${ }^{16}$ WIVIURKA, Eduardo Seino. Transdisciplinaridade do direito. Anais do XIX Encontro Nacional do COMPENDI, Fortaleza, 2010, p.5116).
} 


\section{Serviço social na solução dos conflitos de direito de família}

Dentre as possibilidades de auxílio ao Juiz de direito existe a perícia que é um tipo de prova que o ajuda a formar seu convencimento. Assim como no caso dos psicólogos, os assistentes sociais exercem um serviço técnico que está além das atribuições do juiz de direito e assim emite um laudo após realização do seu trabalho que será de suma importância nos autos do processo.

O serviço social, enquanto participante das práticas judiciárias, se utiliza do inquérito e do exame para, no atendimento que realiza, pesquisar "a verdade". O assistente social é solicitado pelo Judiciário como sendo elemento neutro perante a ação judicial para trazer subsídios, conhecimentos que sirvam de provas, de razões para determinados atos ou decisões a serem tomadas. Através de técnicas de entrevistas, visitas domiciliares, observações, registros, realiza o exame da pobreza e dá o seu parecer sobre a situação investigada e a medida mais adequada a ser aplicada ao menor ou à pessoa da família que estiver envolvida no caso. (FÁVERO, 1999, p. 64 apud MARTINS, Cristina Lempek, Serviço Social no Direito de família, Florianópolis, 2008).

Na seara cível, da qual o direito de família faz parte, o assistente social pode atuar fazendo perícias e laudos em destituições de poder familiar, processos de adoção, colocação familiar, na analise de alguma situação de risco, processos de tutela, curatela, alvará judicial eoutros.

\section{Decisões inovadoras de direito de família que tiveram repercussão na atualidade}

Como mencionado, o direito de família é uma das áreas que mais sofreram com a rapidez das mudanças e modernidade sem controle. Assim, imputa grandes desafios ao judiciário para dizer o direito de forma justa e tentar satisfazer quem procura a imparcialidade da justiça.

Nesse sentido, serão comentadas algumas decisões inovadoras que foram proferidas nos últimos dois anos.

\section{Autorização pelo STJ de desconstituição de paternidade após 5 anos de convívio}

Sob alegações de que só descobriu após exame de DNA que não era o pai biológico da criança, o pai requereu a desconstituição da paternidade no registro de nascimento, mesmo após já estar convivendo com a criança como pai há 05 anos. A decisão foi da terceira turma do STJ ${ }^{17}$. O relator do processo foi o ministro Paulo Cesar Mellize, e segundo ele, ficou comprovado no processo que se o pai soubesse que não era o pai biológico da criança não teria registrado como seu filho. Essa decisão foi publicada no site do STJ no dia 04 de abril de 2015.

\footnotetext{
${ }^{17}$ Comentários disponíveis em https://www.facebook.com/stjnoticias?ref=br_rse também no site www.sti.jus.com.br. O número do processo não foi disponibilizado por ser caso amparado por segredo de justiça.
} 
Mensagens de whatsapp usadas e aceitas como provas de suposta paternidade e concessão de al imentos gravídicos

O processo teve origem na quinta vara de família da cidade de São Paulo. Como provas foram anexadas conversas de whatsapp em que a mãe e o suposto pai chegaram a combinar de ter relações sexuais sem proteção. Foram concedidos os alimentos gravídicos à gestante baseados em 1,5 salários mínimos. Decisão foi proferida em 06 de outubro de $2014^{18}$.

Цuiz gaúcho decide que filho civilmente incapaz tem direito de continuar recebendo pensão al imentícia após maioridade

Um pai recorreu de decisão que o condenou ao pagamento de 30\% do salário mínimo a seu filho que atualmente conta com 39 anos de idade, portador de esquizofrenia severa, porém também recebe além dos alimentos um benefício da previdência. O Tribunal de Justiça do Rio grande do Sul, em decisão unânime negou o recurso e conservou a decisão de manter os alimentos. Decisão proferida em 11 de junho de2014 ${ }^{19}$.

Em execução de alimentos, executado tem nome inscrito nos Serviços de proteção ao $\underline{\text { crédito }}$

Com justificativa de não existir nada expresso que permita, mas também não haver disposições de proibição, executado em ação de alimentos teve nome registrado nos serviços de proteção ao crédito. A dívida era líquida, certa e exigível, porém, as tentativas de penhora de bens ou penhora Online não obtiveram sucesso. A restrição no nome do executado surge como mais uma possibilidade de intimidar o devedor e forçá-lo ao pagamento. Decisão foi publicada em agosto de 2014, o processo teve inicio em $2013^{20}$.

\section{Decisão determina que casal tenha "posse" comp artilhada de cão de estimação após efetivação de divórcio}

A 22a câmara cível do Rio de Janeiro concedeu guarda compartilhada a casal que se divorciou após união de mais de 15 anos. A decisão de primeiro grau concedeu a guarda à mulher, mas o recorrente alega que o cão foi

\footnotetext{
${ }^{18}$ MENSAGEM whatsapp usada como prova de suposta maternidade, Consultor jurídico, São Paulo, 23 outubro 2014. Disponível em http://www.conjur.com.br/2014-out-23/mensagem-whatsapp-usada-prova-suposta-paternidade.

${ }^{19}$ Filho maior incapaz tem direito à pensão alimentícia, IBDFAM (Instituto Brasileiro de Direito de Família), São Paulo, 11 junho de 2014, disponível em:

<http://www.ibdfam.org.br/noticias/5360/Filho+maior+civilmente+incapaz+continua+recebendo+pens\%C3\%A3o+aliment $\%$ C3\%ADcia+decide+TJRS> acesso em 21 maio 2015 às 23:28.

20 - TJSC - Ai no 20130067976, Relator Trindade dos Santos, 2a Câmara de Direito Civil Julgado, J.14/08/2013.
} 
uma compra sua para presentear a antiga companheira e que ele teria muito apego ao cão que já estava com idade avançada e necessita de cuidados especiais. O recorrente conseguiu posse compartilhada do cão que no caso, ficará com ele em finais de semana alternados. O julgador alega falta de legislação que discipline esse assunto, mas justifica decisão com base na dignidade humana do recorrente, entre outros fatores. Decisão proferida em abril de $2015^{21}$.

Viúvo ganha direito de 1 icença “maternidade" de seis meses para cuidar do f ilho recém$\underline{\text { nascido }}$

Apesar de não ser considerada de natureza familiar, merece a decisão ser mencionada pelo fato de ter sido decidida com base no bem estar e na dignidade da criança envolvida, agora que o pai tem que literalmente suceder a mãe que faleceu logo que a criança nasceu. $O$ pai, policial que mora na cidade de Brasília, ficou viúvo quando a criança estava com 34 dias de vida, precisando de tempo e também recursos financeiros para cuidar do bebê que ficou sob sua responsabilidade. A Juíza Ivani Silva da Luz da 6ª vara federal de Brasília concedeu licença paternidade de 120 dias nos moldes de licença maternidade, com acréscimo de 60 dias que é dado às servidoras federais com base no (Decreto n. 6.690/08). A juíza também motivou sua decisão no art. 227 da CR que faz previsão à obrigação concorrente da família, sociedade e Estado de zelar pelo bem das crianças e adolescentes, também enfatiza a juíza que a proteção à infância é um direito que está entre osfundamentais ${ }^{22}$.

\section{CONCLUSÃO}

Analisamos um pouco do que já foi a sociedade e buscamos o entendimento também do que ela se tornou ou ainda está se tornando, tendo em vista que as mudanças são constantes, o que reflete diretamente no nosso ordenamento jurídico.

O autor Zygmunt Bauman, que forneceu um pilar para o presente estudo demonstrou com seus grandes pensamentos a insatisfação constante dos seres humanos, que o levou a alcançar à instantaneidade e extraterritorialidade. Assim, não mensuramos aonde vamos ainda querer chegar e se conseguiremos chegar.

A nossa sociedade ganhou muitos presentes com a modernidade líquida: Liberdade, tecnologia, descobertas científicas, etc. No entanto, as maldições da modernidade também são muitas; durante muito tempo a evolução se deu de forma irracional, os recursos naturais foram destruídos com a evolução, valores e modelos

21 - JUDICIÁRIO Tribunal de Justiça do Rio de Janeiro, Apelação cível No 0019757-79.2013.8.19.0208, Relator Des. MARCELO LIMA BUHATEM, abril de 2015.

${ }^{22}$ Viúvo ganha na justiça direito à licença maternidade de seis meses para cuidar de filho, Uol notícias cotidiano, São Paulo, 13-022015. Disponível em <http://noticias.uol.com.br/cotidiano/ultimas-noticias/2012/02/13/viuvo-ganha-na-justica-direito-alicenca-maternidade-de-seis-meses-para-cuidar-do-filho.htm> acesso em 22 maio de 2015 às 00h50min. 
que todos achavam que deveriam ser rompidos foram derretidos de tal maneira que ficou difícil distinguir o que é normal e moral. Por isso é tão importante um ordenamento jurídico sensato e atualizado para controlar a sociedade. O autor Zygmunt Bauman fala em limite, pensa estar no fim dos tempos, pois fica realmente difícil mensurar o que teremos pela frente em questões de humanidade, sociedade, justiça, meio ambiente e consequentemente do direito.

No que tange ao direito acredito que temos leis muito boas em sua variedade de áreas. Costumamos dizer que as leis sempre são elaboradas e publicadas com atraso, mas sabemos que isso envolve muitas questões, pois a modernidade é rápida, o procedimento de criação de leis é complexo e ainda existem os interesses políticos que sempre leva o governo a priorizar os projetos que tem mais interesses envolvidos, e outros que são importantes talvez com projetos empilhados sem votação duranteanos.

No direito de família a cada dia temos notícias de uma inovação, como foram citadas algumas delas no presente trabalho. As possibilidades de uniões são diversas, a dissolução do vínculo também tem sido a cada dia mais comum e facilitado e solucionar os problemas decorrentes dessas tantas famílias (de banalidades a problemas graves) com certeza não é tarefa fácil. Por isso tão imprescindível a amplitude da análise do fato e da psicologia, serviço social e as outras ciências que podem facilitar o trabalho do juiz para fazer justiça.

Como ressaltado no decorrer do trabalho a aplicação do direito tem se baseado em hermenêutica com interpretações amplas, pois a melhor maneira de termos maior cognição do processo no contexto social é essa. As decisões não seriam justas nem em consonância com a evolução social que traz tantos novos casos se fosse feita apenas interpretação literal das normas. O direito é transdisciplinar, deve ter interpretação interdisciplinar, pautarse na razoabilidade e na proporção para conseguir solucionar tantos casos novos que surgem a cadadia.

Ocorre que, ao mesmo tempo em que mencionamos a necessidade de hermenêutica pautada em direitos fundamentais e princípios surge também paralelamente as desvantagens dessa possibilidade de ampliar as decisões. Uma das regras da interpretação seria a de ampliá-la, mas se atendo à norma e ao fim que o levou a ser criada e seu objetivo na sociedade, mas nem sempre é o que acontece. As posições doutrinárias são em correntes diversas, às vezes ampliando demais o sentido do texto da lei de forma quase a modificá-lo e as decisões dos tribunais variam demais, o que causa uma insegurança jurídica muito grande como, por exemplo, o caso do relator que concedeu o cancelamento do reconhecimento de paternidade de um menor que já conta com 05 anos de idade, fugindo da jurisprudência dominante sobre o assunto que prevê o contrário. $\mathrm{O}$ fato é que o papel do julgador é cada dia mais complexo e a modernidade líquida apesar de trazer muitas vantagens e possibilidades também trouxe muitos malefícios.

É dificil fazer uma projeção do que o ser humano ainda vai desejar e o que ainda vai conseguir, e até que ponto nossas leis e nossas formas de aplicá-las vão ter que ser modificadas para acompanhar a modernidade sem 
controle. O que é certo é que a insatisfação faz parte da natureza de cada indivíduo que sempre olha pra realidade imaginando que pode ser melhor, assim como enxergamos nossa justiça ineficiente e com possibilidade de fazer mais e melhor para a sociedade.

\title{
THEORY OF LIQUID MODERNITY - SOCIAL FLUIDITY AND NEW CHALLENGES IN THE INTERPRETATION OF LAWS FOR SOLUTION OF VARIOUS NEW CONFLICTS IN FAMILY LAW
}

\begin{abstract}
The society is very dynamic, evolution occurs in an uncontrolled manner, and those positive and negative points. In addition to arise lot and several conflicts natures, they sometimes run away from legal provisions, given that the legislation does not always accompany the rapidly changing. Conflicts are increasingly complex, making it difficult increasingly fair application of the law. So in that sense, there is the need for broader interpretation, hermeneutics true considering the law as a whole, the right that is beyond the law, and must have as its main purpose to apply the right decisions to those who resort to the judiciary, ie the right which is based on fundamental principles and rights of each individual. The metaphor of liquid modernity, the idea of a very renowned sociologist, "Zygmunt Bauman" has been studied and associated with the new challenges of applying the law, paying off so its study and understanding. In this study, the approach will emphasize the great and so many changes with regard to familylaw.
\end{abstract}

Keywords: Modernity. Social Fluidity. Conflicts. Interpretation. ZygmuntBauman.

\section{REFERÊNCIAS BIBLIOGRÁFICAS}

ALEXY, Robert. Teoria dos Direitos Fundamentais. São Paulo: Malheiros Editores.1985 (Tradução brasileira de Virgílio Afonso da Silva).

BAUMAN, Zygmunt. Modernidade Líquida, Rio de Janeiro: Jorge Zahar Ed., 2001.

COSTA, Helder Ferreira Lisboa da. História do Direito: de Roma à História do Povo Hebreu muçulmano: evolução do direito antigo à compreensão do pensamento Jurídico contemporâneo. Belém: Unama, 2007 p.2633.

DINIZ, Maria Helena, 1999.p.132 (apud LIMA, Rogério de Araújo; LIMA, Lucas Cavalcante de, 2011.p.1).

FRANÇA, R. Limongi. Hermenêutica jurídica. São Paulo: Revista dos Tribunais, 2009, 9 ed..

LIMA, Rogério de Araújo; LIMA, Lucas Cavalcanti de. Culturalismo, história e normativismo: A arte de fazer direito na Mesopotânea ao Egito Antigo. Jus navigandi, Teresina, ano 16, n 3013, lout.2011, disponível em<http://jus.com.br/artigos/2007> , acesso em 20 fev2015

PIETRO, Zanela de; MELLO, Celso Antônio Bandeira de (apud Princípio da proporcionalidade versus 
razoabilidade, Diego Bruno de Souza Pires, UNEB (Universidade Estado da Bahia), disponível em www.ambitojuridico.com.br- acesso de 17.05.2015)

OLIVEIRA, Caio Vinícius Carvalho de. Distinção entre razoabilidade e proporcionalidade. Revista Jus Navigandi, Teresina, ano 17, n. 3337, 20 ago. 2012. Disponível em: <http://jus.com.br/artigos/22438>. Acesso em: 17 maio 2015.

BECK, Ulrich apud BAUMAN, Zygmunt. Teoria da Modernidade Líquida. Rio de Janeiro: Zahar,2000.p.13.

FAVARO, Diocélia da Graça Mesquita. Interdisciplinaridade, sua importância na formação jurídica e sua aplicação ao Direito de família. Revista Cesumar. V.5. N.1.p 209-232,2005.

WIVIURKA, Eduardo Seino. Transdisciplinaridade do direito. Anais do XIX Encontro Nacional do COMPENDI, Fortaleza, 2010, p.5116).

Notícias caso revogação reconhecimento de paternidade, Caso disponível em <https://www.facebook.com/stjnoticias?ref=br_rs> também no site www.stj.jus.com.br, acesso em 20/05/2015.

Mensagem whatsapp usada como prova de suposta maternidade, Consultor jurídico, São Paulo, 23 outubro 2014. Disponível em http://www.conjur.com.br/2014-out-23/mensagem-whatsapp-usada-prova-supostapaternidade.

Filho maior incapaz tem direito à pensão alimentícia, IBDFAM (Instituto Brasileiro de Direito de Família), São Paulo, junho de 2014, disponível em <http://www.ibdfam.org.br/noticias/5360/Filho+maior+civilmente+incapaz+continua+recebendo+pens\%C3\% A3o+aliment\%C3\%ADcia+decide+TJRS> acesso em 21 maio 2015 às23:28.

TJSC.Ain ${ }^{\circ}$ 20130067976, Relator Trindade dos Santos, 2a Câmara de Direito Civil Julgado, J. 14/08/2013.

JUDICIÁRIO. Tribunal de Justiça do Rio de Janeiro, Apelação cível No 0019757-79.2013.8.19.0208, Relator Des. MARCELO LIMA BUHATEM, abril de 2015.

Viúvo ganha na justiça direito à licença maternidade de seis meses para cuidar de filho, Uol notícias cotidiano, São Paulo, 13-02-2015. Disponível em <http://noticias.uol.com.br/cotidiano/ultimas-noticias/2012/02/13/viuvoganha-na-justica-direito-a-licenca-maternidade-de-seis-meses-para-cuidar-do-filho.htm > acesso em 22 maio de 2015 às $00 \mathrm{~h} 50 \mathrm{~min}$.

Trabalhoenviadoem23denovembrode2015.

Aceitoem03 demarçode2016. 